SOUTH AFRICA IN MY FANTASY WORLD

'From bushveld through deserts and forests, up winter snow clad peaks down to wide, unspoiled beaches and coastal wetlands, lies the sprawling land called South Africa. This land of unequalled splendour and diversity beckons you.....' These words, from the SATOUR website description of South Africa, entice multitudes of tourists to our exquisite beaches and sites all year round. There is no doubt that with so much exceptional natural beauty South Africa is a popular tourist destination. On just one such perfect day recently, under cornflower blue Cape Town skies, with the soothing sound of rolling waves in the background and the fragrant smell of fresh spring flowers, I dreamed of a perfect South Africa.

In this fantasy South Africa, cricket was played - well, like cricket should be played, and bribing and betting were kept to the blackjack tables. Every child had equal schooling opportunity,

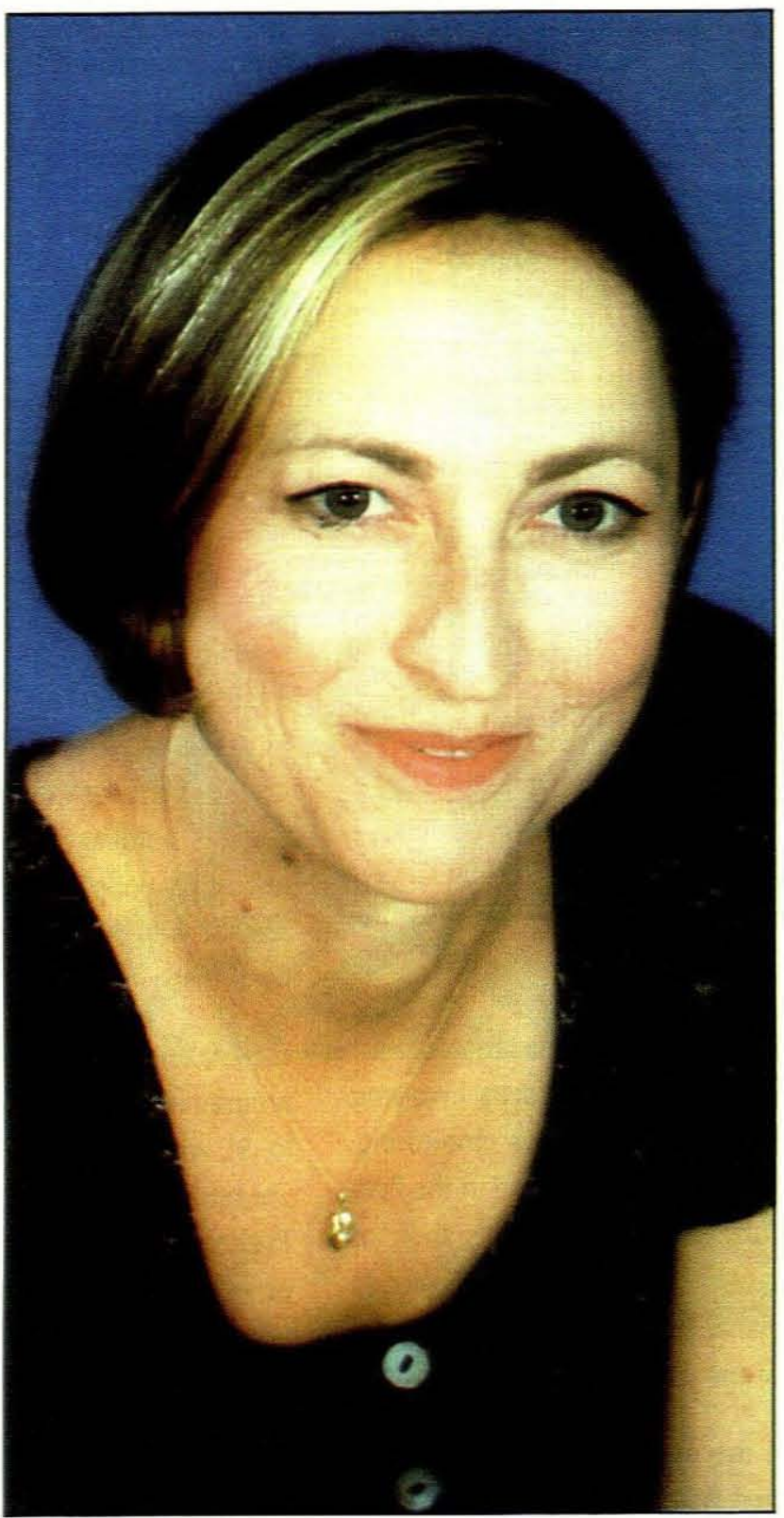

funding to well-organised targetdriven primary prevention programmes that resulted in a falling HIV incidence rate among our young population. This same leader was frequently seen visiting the sick and orphaned listening to their plight and doing all that he could to alleviate the suffering that HIV inflicts. He had issued a loud call to arms to al governmental ministers, departments and organisations to mobilise all resources in all areas so as to tackle this challenge head-on. Every expectant mother throughout the country had access to non-discriminatory HIV testing and the choice of maternal transmission prophylaxis and formula feeding. In this dream our president had called in African and local experts to advise on the best methods for providing equal and costeffective universal access to antiretrovirals. South Africa was blazing a trail and was foremost in showing the way to other African countries with regard to providing comprehensive care for the HIV-infected. This provided an inspiring example of how to and all experienced the joy of learning from enthusiastic educators equipped with more than minimal learning aids. In this perfect South Africa minibus taxis indicated when stopping and gave way politely to pedestrians. Tax payers' money went to social upliftment and provision of clean water and housing for all, rather than on submarines and warheads. The gravy train was traded in for an AIDS awareness 'Lovelife' train. Personal safety and private belongings were not violated by sundry thieves and criminals. There was more job security for our rugby coaches and the Rand rallied and even superseded the Dollar!

Court cases were used to bring criminals to book, and were not needed to bring rationality to government policy. Presidential campaigns from neighbouring states to the north were based on sound legal and humanitarian principles - despots were not tolerated and were quickly and effectively deposed.

In this wonderful, vivid dream, our own president directed state utilise cheaper agents and truly African-friendly methods of drug provision and monitoring.

But then - Poof! - the dream ended and reality swept in. While the world observed World AIDS day, and many in this country attended remembrance services, art exhibition openings and other sundry activities to commemorate and heighten HIV awareness, our president attended a meeting of the ANC national executive committee. His spokesperson hastened to assure us all that he was involved via 'institutions' and that his deputy was dealing with the problem of HIV/AIDS while presumably he dealt with more pressing problems.

One such institution which Jacob Zuma does chair is the South African National AIDS Council (SANAC). Even if you are involved in HIV care you would be forgiven for not knowing about the existence of this council, despite the recent publicity it received for the dubious highlight of SANAC's year being the launch of the government's HIVIAIDS programme in Braille. The deputy 
chief executive, Yacoob Abba-Omar, feels that SANAC's work has "been penetrating deeper and deeper and whilst its profile [isn't] great, the effect has been felt.' In the words of another council member, 'the last 2 years have been putting the building blocks in place and the council [is] still in the developmental phase.' A classic case of 'while Rome burns.' I am inclined to prefer the words of Lucky Mazibuko. He too is a council member but acknowledges that the mood among members is one of dissatisfaction, that little difference has been made and that SANAC should rather be an independent body since the government tends to dominate.

Government domination seems to be another recurring theme recently. I was very dismayed to see that the Human Rights Commission (HRC) had pulled out from the Treatment Action Campaign's (TAC) mother-to-child court case because of government pressure. Anne Routier, the former chairperson of policy and planning of the same HRC recently asked if the HRC is too effete to stand up for those who cannot yet stand, namely those pregnant women throughout the country who face the possibility of transmitting the virus to their unborn children and who currently have no opportunity to do something about it. She ends her comments with an even more powerful question: how long will the $\mathrm{HRC}$, which has the strongest powers of any human rights commission in the world, continue to roll over and lie down?

Even more disturbing in this pattern of government influence was the apparent retraction of statements by our former president on World AIDS Day. I was thrilled to read on front page news that Nelson Mandela had visited Beautiful Gate in Crossroads and had sent a clear message to the government: 'Heads of State and their first ladies must be in the forefront of the campaign to fight AIDS. We must combine various strategies with giving people the necessary drugs to prevent the disease getting the upper hand'. But then just a few short hours later at the opening of the Nelson Mandela Gateway to Robben Island, the former president said that journalists had misinterpreted the comments he had made earlier in the day at Crossroads and rejected that he had in any way attacked Mbeki's stance on AIDS. This retraction seemingly followed a phone call from Mbeki's office after his visit to the AIDS Care Centre. One wonders how we will ever get out of this impasse if constructive criticism is not tolerated and institutions are hamstrung by the need to conform to government policy regardless of how wrong or harmful it is.

A highlight of my own World AIDS Day activities was attending the opening of the Higgin's Trust photographic exhibition entitled 'Positive Lives'. Zackie Achmat opened the exhibition and in his quiet but forthright way questioned why a court case such as the MTCT case against the government was even being waged this week. The futile waste of energy, time and resources required to bring our government thinking into line with the rest of the continent, and indeed the world, is saddening.

The exhibition currently running at the South African National Gallery of Art until March is wonderful. Poignant pictures and stories from artists worldwide are captured and those of you familiar with Gideon Mendel's work will see an abundance of it on display. In the words of Zackie, those of us who are continually in the business of caring for, fighting for, supporting and treating those who have been infected and affected by HIV and AIDS will have the opportunity, when standing in front of these pictures and portraits, to mourn and grieve, and this is a good thing to do. I highly recommend the pilgrimage.

\section{LINDA-GAIL BEKKER}

Managing Editor 